\title{
皮革関連産業事業所建築から見た台東区北部地域の職住混在空間特性 地域産業空間構造から見た都市部職住混在空間の実態と継承に関する研究その 2 \\ SPATIAL CHARACTERISTICS OF RESIDENTIAL-INDUSTRIAL MIXED-USE AREA IN NORTHERN TAITO-WARD FROM THE VIEWPOINT OF LEATHER INDUSTRY BUILDINGS
}

A study on the fact and inheritance of urban Residential-Industrial mixed-use area

from the view of Regional-Industrial structure Part2

顅田＼cjkstart愛*1, 中島直人*2, 西村幸夫*3

Megumi HAMADA, Naoto NAKAJIMA and Yukio NISHIMURA

\begin{abstract}
Northern Taito Ward is an area where the leather industry has located from early modern times. To incorporate the perspective of industrial structure with the discussion on the mixed-use spaces, this study disclosed the spatial characteristics of leather industry buildings (owned by individual owners) and analyzed their relationship with regional-industrial structure.

Through field survey of 155 buildings, it found that there are 4 main types of modern urban residential-industrial mixed-use buildings in the area. From the view of area analysis, the special characteristics of the urban residential-industrial mixed-use buildings are different according to the regional-industrial structure and transition of leather industry.
\end{abstract}

Keywords: Urban industry, Industrial spaces, Leather industry, Taito-Ward, Residential-Industrial mixed use, Regional structure 都市産業，産業空間，皮革産業，台東区，職住混在，地域構造

1. はじめに

\section{1. 研究の背景と目的}

東京都市部の既存市街地では、都心回帰に伴う住宅開発や都市開 発諸制度により人口構成や空間の大規模化や高度化を伴う集約・再 編が実施されてきた ${ }^{1)}$ 。一方、グローバル化に伴う新しい価值を創 造する中小・ベンチャー企業などの小さな経済主体の強化 ${ }^{2)}$ や ICT などを活用した時間や場所にとらわれない柔軟な働き方が求められ ており ${ }^{3)}$ 、それらの活動拠点としてコワーキングスペースや SOHO など多様で小規模な空間基盤にも注目が集まっている ${ }^{4)}$ 。

本研究では生活空間注 1) と産業空間が融合した持続可能な産業都 市空間の形成 ${ }^{5)}$ に向け、上述の社会動向を受容しつつある都市空間 として、近世より伝統的に小規模な単位で職住混在が形成・維持さ れてきた都市部の地場産業集積地に着目し、そのミクロな職住混在 空間の実態と特性を把握する。第 1 稿 ${ }^{6)}$ では、台東区北部皮革関連 産業集積地を対象に 1970 年から 2016 年のエリア内の地域産業空 間構造の変遷を明らかにした。本稿では引き続き同対象地において、 以下の 3 点を目的とした研究を実施する。

(1) 形成されている職住併存型都市住宅の実態を明らかにするこ とで、建築スケールでの職住混在空間特性を把握する
(2) 職住併存型都市住宅の地域内における立地の展開を見ること で、エリアスケールでの職住混在空間特性を把握する

(3) (2)の結果を地域産業空間構造の観点から分析し、都市部の小規 模な職住混在空間の形成と継承に関する示唆を得る

\section{2. 東京都区の住工混在をめぐる議論の系譜}

(1) 地理・経済分野における住商工混在地域の地域構造論の展開

井出(1966） ${ }^{7)}$ は東京都における日用消費財工業の地理的分布と地 域構造を解明し、東京の日用消費財生産の中心をなす城東地域では 「製造卸」注 2) が支配的構造であることを明らかにした。また井出 (1973) ${ }^{8)}$ では、それまで機能配置的に表面上の議論で行われてきた 用途地域指定に対して問題提起し、産業流通上の繋がりや地域構造 と絡めた議論に向け、東京都区部の各業種が重合するコンプレック スエリア(住商工混在地域)の地域構造からの分析を実施している。 竹内 $(1974)^{99}$ はこれを受け、複雑な実態をもつ「住工混在地域」 というエリアの生産と居住が一体的な地域としての機能を正しく評 価し、工場集積の再編成や再開発に向けた大都市工業研究における 当該エリアの広域的位置付け及び詳細な調査分析の必要性を唱えた。

\section{(2) 都市計画・建築分野における住工混在地の立地と都市空間論}

これらの流れを汲むような形で、東京都区における用途混在地の

\footnotetext{
*1 東京大学大学院工学系研究科都市工学専攻 博士課程 $\cdot$ 工修

*2 東京大学大学院工学系研究科都市工学専攻 准教授 $\cdot$ 工博

*3＼cjkstart神戸芸術工科大学大学院芸術工学研究科 教授・工博
}

Grad. Student, Dept. of Urban Engineering, School of Engineering, The University of Tokyo, M.Eng.

Assoc. Prof., Dept. of Urban Engineering, School of Engineering, The University of Tokyo, Dr.Eng.

Prof., Graduate school of Kobe Design University, Dr.Eng. 
位置付け及び再評価の議論が、高度成長期を過ぎた $1970-80$ 年代 頃から主に大田区を中心として行われてきた。

中出 $(1982)^{10)}$ は、都市には一定量の工業は必要でありその維持に おいて混在地域の存在が保証されるべきとの立場に立った上で、大 田区住工混在地域を対象にこれまでの工場用地に住宅が入り込む形 態とは異なり工場の発生および工場付きミ二開発による小零細規模 工場の再生現象を「新たなる混在」として報告し、マンションなど の宅地開発も従業員らの職住近接関係を維持する住み替えの一要素 としての見方を提示している。また中出(1983) ${ }^{11)}$ では東京都区部全 体における混在地域の広がりとそれぞれの位置付けを実施している。 永野(1987) ${ }^{12)}$ も同様に住工混在地区の整備の重要性を説き、大田区 における即地的調查に基づいて跡地開発や建替などの地域整備に向 けた合理的かつ具体的な整備手法の提案を実施している。

1990 年代からはこれまでの立地および土地利用的な分析から、更 に地域に踏み込む形で解像度を高めた街区・建物スケールでの空間 に基づいた研究が行われるようになってきた。和田ら(1992) ${ }^{13)}$ では、 同じく住工混在地域を積極的に評価するという視点のもとで、大田 区大森地区における街区レベルでの住工混在状況とその変化を明ら かにし、混在の深化を明らかにした。和田ら (1994) ${ }^{14)}$ では大田区お よび板橋区を中心とした街区レベルでの土地利用変化を分析し、敷 地レベルでの混在プロセスおよび防止策としての最低敷地面積制限 の有効性に関する議論を実施している。

また近年は人口減少下で住戸内の非居住機能に関する議論が行わ れており、佐久間ら $(2009){ }^{15)}$ は東京都のニット産地(墨田区)を対象 に建築スケールでの事業所建築物および職住関係の実態を明らかに した点で新しい。同時に、地域内部の地域住民および地域コミュニ ティなどのソフトな関係性に関する研究も行われるようになってき た。清水ら $(2007)^{16)}$ の研究では、住工の混在地を持続可能なまちづ くりの中で積極的に位置付け、兵庫県尼崎市の住工共存維持ゾーン において工場跡地に建てられた住宅住民及び混在地で操業する事業 所に対するアンケート調查を実施し、相互の意識や満足度の比較を 実施している。また大熊ら (2011) ${ }^{17)}$ は、大田区大森南地区を対象に ヒアリングに基づく住工共存地区における産業ネットワークと地域 ネットワークの分布及び重叔合わせ分析を実施し、産業政策と生活 支援を連携させる必要性を唱えている。

\section{(3) 本研究の位置づけ}

本研究は既往の議論の系譜に則り、地場産業地域における産業都 市空間の実現に向けた観点から、用途混在地を評価する立場に立つ。 1970 年代から土地利用分析を始めとし、近年は実態的な地域生活空 間からの分析が行われてきたこれまでの住工混在地の空間論では、 比較的「職住」の「住」の視点から考察している研究が多く、都市 部職住混在空間の本質的な実態の解明には、もう一方の「職」であ る業務空間やその地域産業空間構造の視点からの研究も並行して実 施していくことが重要であると考える。よって、建築・エリアスケ ールにおける職住混在都市空間の分析に地域産業空間構造の視点を 組み込むこと、従来の住商や住工の混在論に対し、産業構造の核と なる製造卸が集積した「住・商・工」の混在地の職住混在空間の実 態を明らかにしていること、などが本研究の特徴的な点である。

併せて、これまで立地論に留まっていた、対象地である台東区北 部地域の職住混在空間の実態と特性に関する研究を、よりミクロな
建築・エリアスケールにおいて実施し、形成されている都市空間を 共時的に報告するものである。

\section{3. 用語の使い分け}

本研究において「地域産業空間構造」とは、各「産業部門(業種)」 の機能・取引のネットワークシステムとしての「産業構造」に、一 定のエリア内における空間的な展開まで含めた概念として使用する。 「職住一体」とは同建物内で居住機能と業務機能が併存しており且つ 居住者及び事業従事者が一致する場合を以て表現する。対して「職 住併存」とは、同建物内で居住機能と業務機能は共存しているもの の、事業者と居住者が同一とは限らない場合に使用寸るものとする。 また「職住混在空間」とは、「職 : 業務」と「住 : 居住」という機能 空間の建築・エリアスケールでの混在を表す。

\section{2. 調查概要 \\ 2. 1. 調査対象の抽出 \\ (1) 対象産業部門 :}

本調査では 2016 年タウンペ ージに記載されていた皮革関 連産業事業所のうち、1970 年 「靴産業名鑑」の産業分類にお ける「靴製造」「靴卸」「皮革の 製造販売」「附属材料」に対応す る事業所注3)を対象とする注4)

\section{(2) 対象範囲}

同心円状に南北に広がる地 域産業空間構造特性に着目し、 第 1 稿 $\left.{ }^{6}\right)$ の対象範囲注 5 のうち、 部門別の立地との対応の検討 が容易な以下の町丁目を対象 とし、4 地区に分けた(Fig.1)。 ·橋場地区: 橋場 $1 \cdot 2$ 丁目 (21 軒)

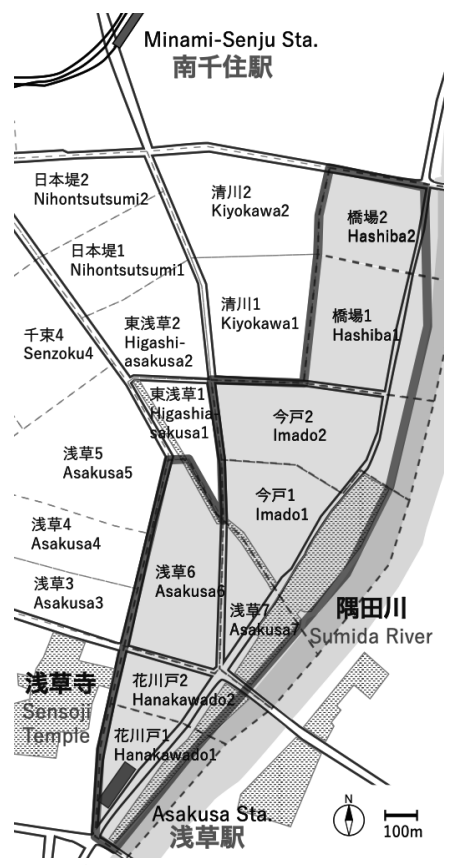

Fig. 1 Site of Survey ·今戸地区: 今戸 $1 \cdot 2$ 丁目 $(54$ 軒 $)$

- 浅草 $6 \cdot 7$ 地区：浅草 $6 \cdot 7$ 丁目 (69 軒)

·花川戸地区 : 花川戸 $1 \cdot 2$ 丁目 (11 軒)

以上により選定された事業所 183 件注 6) のうち、現地において調 查・判別の可能であった 167 件のデータを元に分析を実施する。ま た、調査不可能であった 16 件のうち、14 件は特定不明・建物特性 の調査難注7)であり、2 件は取り壞しまたは移転してしまった跡であ った。また全 167 件の内 12 件は部門の重複が見られるが、部門を 重視して各々を別事業所としてカウント寸る形で分析を実施してい るため、建物の実数としては 155 軒である。

\section{2. 調査の方法}

a）選定された 167 件の事業所を対象に、2017 年 4〜 7 月に現地 踏查を実施し、職住併存型都市住宅の特性を把握した。(第 3 章)

b) 用途形態などのデータを元に職住併存型都市住宅の類型の作 成並びに外観に表出する居住要素の分析を実施した。(第 3 章)

c）建物類型や外観の居住要素の地域内の立地傾向からエリアレ ベルの職住混在空間特性を把握した。(第 4 章)

d）エリアレベルでの職住混在空間特性と皮革関連産業部門別の 地域産業空間構造の関係性を検証した。(第 5 章) 


\section{3. 建築スケールにおける職住混在空間特性}

\section{1. 対象建物形態の実態}

Fig. 2 に地上階数と木造・非木造の関係を図示する。現地踏査した 155 軒の物件のうち約 8 割が非木造であることが確認できた。注 8$)$ ま た、 6 割以上は 4 階以下の建築物で構成されており、2 階建て建物 は主に木造だが、今後個別更新が進んだ際には非木造に構造を変化 させて中高層化して行くことも予想できる。

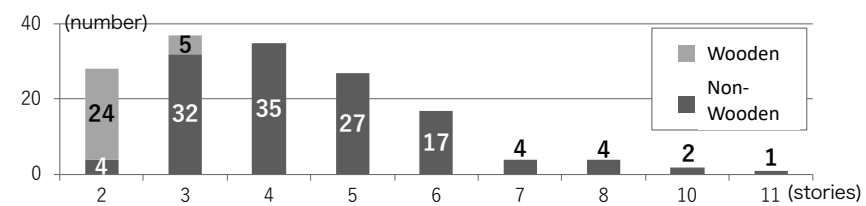

Fig. 2 Number of Building Stories and Wooden Structure

\section{2. 対象建物の類型（職住併存型都市住宅の抽出）}

対象の事業所建築は、建物用途・形態並びに建替時期による変化な どを考慮すると、以下の 8 種類 $(\mathrm{A}, \mathrm{B}, \mathrm{C})$ が確認できた(Table1)。「職 住併存型都市住宅」とは、類型 $\mathrm{A}$ の総称として表現する。本研究で は事業所用途の混在性及び小規模の更新を重視して、主に A1、A2、 A3、B1 に着眼し、その特徴を以下の Table2 にまとめる。軒数は A2 が最多で、次に B1 が多い。また佐久間 $(2009){ }^{15)}$ における分類手法 を参考にしながら作成した本類型の判断基準を、Fig.3 に示寸注 9)。

Table 1 Classification of Target Buildings

\begin{tabular}{|c|c|c|}
\hline $\begin{array}{l}\text { A : 職住併存(立体的混入) } \\
\text { Industrial-Residential Mixed-Use }\end{array}$ & $\begin{array}{c}\text { B : 用途純化(平面的混入) } \\
\text { Uniformity of land use }\end{array}$ & $\begin{array}{c}\mathrm{C}: \text { その他 } \\
\text { Others }\end{array}$ \\
\hline 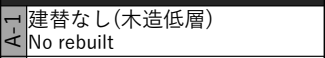 & $\begin{array}{l}-1 \\
\infty \\
\infty\end{array}$ & \multirow{2}{*}{$\begin{array}{l}\text { 集合住宅の一室利用 } \\
\text { One-room use of inside } \\
\text { the collective housing }\end{array}$} \\
\hline $\begin{array}{ll}\sim & \text { 職住(1:1)融合化で更新 } \\
\ll & \text { Rebuilt with fusion of } \\
\text { working and residence functions }\end{array}$ & $\begin{array}{l}\text { 戸建て住宅 } \\
\text { Detached housing }\end{array}$ & \\
\hline \begin{tabular}{l|l}
$m$ & 集合住宅低層部テナント \\
$<$ & Tenant in low-rise part of \\
collective housing
\end{tabular} & \begin{tabular}{l|l} 
集合住宅化 \\
ف
\end{tabular} & $\begin{array}{l}\text { (複合)ビルテナント } \\
\text { Tenant of office building }\end{array}$ \\
\hline
\end{tabular}

Table 2 Characteristics of Main 4 Categories

\begin{tabular}{|c|c|c|c|c|}
\hline & A1 & A2 & A3 & B1 \\
\hline $\begin{array}{l}\text { 外鹳例 } \\
\text { Outlook }\end{array}$ & 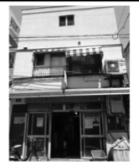 & & $\underline{a}$ & $\begin{array}{r}1401 \\
-\quad 5 \\
\end{array}$ \\
\hline $\begin{array}{l}\text { 構造 } \\
\text { Structure }\end{array}$ & $\begin{array}{l}\text { 木造 / 低層 } \\
\text { Wooden } \\
\text { Low-rise }\end{array}$ & $\begin{array}{c}\text { 非木造 / 中低層 } \\
\text { Non-Wooden } \\
\text { Low-\&Middle-rise }\end{array}$ & $\begin{array}{l}\text { 非木造 / 中高層 } \\
\text { Non-Wooden } \\
\text { Middle-\&High-rise }\end{array}$ & $\begin{array}{c}\text { 非木造 / 中低層 } \\
\text { Non-Wooden } \\
\text { Middle-\&Low-rise }\end{array}$ \\
\hline $\begin{array}{c}\text { 職住関係 } \\
\text { Working \& Residential } \\
\text { relationship }\end{array}$ & $\begin{array}{c}\text { 職 : 住 } \\
\text { (Working: housing) } \\
\quad 1: 1\end{array}$ & $\begin{array}{c}\text { 職: 住 } \\
\text { (Working }: \text { housing) } \\
1: 1\end{array}$ & $\begin{array}{c}\text { 職 : 住 } \\
\text { (Working : housing) } \\
1: \text { multiple }\end{array}$ & $\begin{array}{c}\text { 職: 住 } \\
\text { (Working : housing) } \\
1 \sim \text { multiple : } 0\end{array}$ \\
\hline $\begin{array}{c}\text { 低層部 } \\
\text { Uses of lower floors }\end{array}$ & $\begin{array}{l}\text { 業務/居住 } \\
\text { Workplace } \\
\text { Residence }\end{array}$ & $\begin{array}{c}\text { 車 / 業務 } \\
\text { Garage } \\
\text { Workplace }\end{array}$ & $\begin{array}{c}\text { 車 / 業務 } \\
\text { Garage } \\
\text { Workplace }\end{array}$ & $\begin{array}{c}\text { 車 / 業務 } \\
\text { Garage } \\
\text { Workplace }\end{array}$ \\
\hline $\begin{array}{c}\text { 上層部 } \\
\text { Uses of Upper floors }\end{array}$ & $\begin{array}{c}\text { 居住 } \\
\text { Residenee }\end{array}$ & $\begin{array}{c}\text { 居住 } \\
\text { Residence }\end{array}$ & $\begin{array}{c}\text { 居住 } \\
\text { Residence }\end{array}$ & $\begin{array}{c}\text { 業務 } \\
\text { Works / office }\end{array}$ \\
\hline $\begin{array}{c}\text { 職住入口 } \\
\text { Entrances of workplace } \\
\text { and residences }\end{array}$ & $\begin{array}{l}\text { - Sharing } \\
\text { - Separate }\end{array}$ & $\begin{array}{l}\text { - Sharing } \\
\text { - Separate }\end{array}$ & - Separate & - \\
\hline 軒数 Number & 27 & 62 & 11 & 54 \\
\hline
\end{tabular}

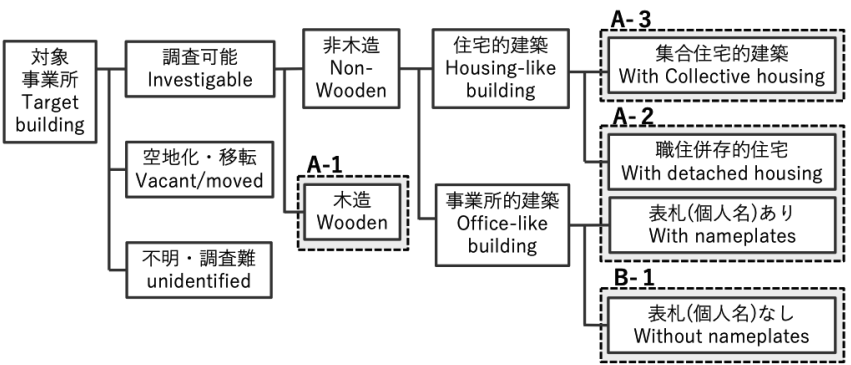

Fig. 3 Criteria for the Typology of Buildings（既往研究を元に筆者作成）

\section{3. 職住併存型都市住宅の外観に見られる居住要素の分析}

現地調査で確認した職住併存型都市住宅の外観や 1 階の間口部分 に表出している機能的な空間要素を整理した。

(1) バルコニーの設置

バルコニーの設置(Fig.4)は A タイプ 100 軒中 67 軒で確認した。建物類型別設置率は A1 約 $48 \%$ 、A 2 約 $66 \%$ 、A 3 が $100 \%$ で、職住併存型 都市住宅の更新に伴い、まち並み景観の変化等 に影響を与える可能性がある。

\section{(2) 動線の分離}

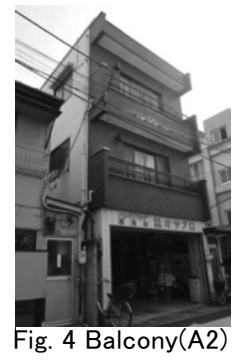

A タイプの職住併存型都市住宅として識別された 100 軒に関して、 業務空間および居住空間の入り口動線のしつらえの関係性を整理し た。Table3 に入り口動線のパターンの分類軒数を示す。側面に接道 がある場合、出入口は間口と別面に取る傾向が見られ、側面に接道 面がないものの過半数は、間口部分を分割して別の入口を取る。

（Fig.6, Fig.7）また集合住宅の共同玄関や駐輪場、車裁き空間等を 1 階にもつ建築は入口を奥に引き込む現象も見られた。Fig.5には、A タイプ 100 軒のうち側面に接道がない 75 軒における、前面間口の 入口動線の分離(別(前面のみ)) と建物類型の関係性を示す。前面のみ に入口をもつ $\mathrm{A} 2 \cdot \mathrm{A} 3$ は大半が 2 つの入口を間口に設けている一方、 A1 は半数以上が 1 つの入口を共有するしつらえとなっていた。

Table 3 Relationship of Each Entrances (type-A only)

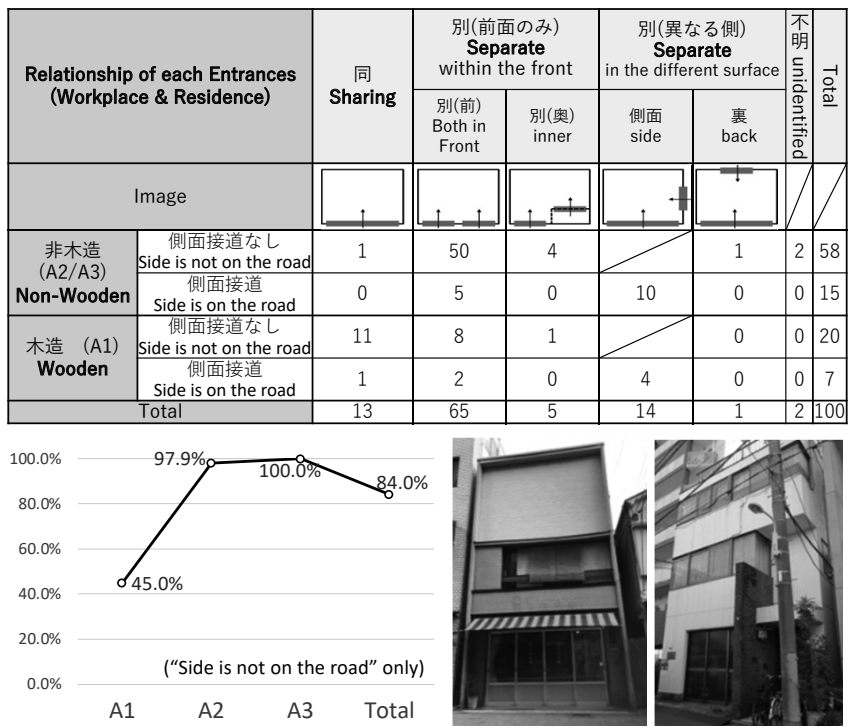

Fig. 5 Entrance Separation Rate

Fig. 6 Sharing Fig. 7 Separate

\section{（3）表札の掲示}

職住併存型都市住宅である A タイプ 100 軒中、表札注 10) を掲 示する事業所は 59 軒確認でき た。特に非木造の $\mathrm{A} 2$ で設置率が 高い(A1 約 52\%、A 2 約 $80 \%)$ また、間口面における入口の分 離と表札掲示関係を示したもの

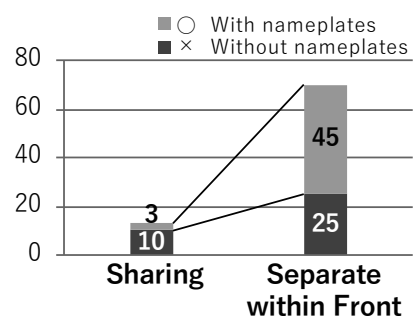

Fig. 8 Relationship Between Nameplate \& Entrance Separation

が、Fig.8 である。これより、動線が分離した職住混在型都市住宅の 方が表札を掲げる傾向が強くなる(約 $23 \% \rightarrow$ 約 $64 \%$ )ことが判明した。 


\section{(4) 道路空間への滲み出し}

道路空間への居住・業務要素の 滲み出し現象が 155 軒中 123 軒 (約 79\%)で確認できた。類型別 では、A1 約 80\%、A2 約 77\%、 A3 約 $82 \% 、 B 1$ 約 $80 \%$ となって おり、比率に大きな違いは見ら

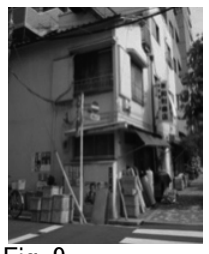

Fig. 9

Business Uses

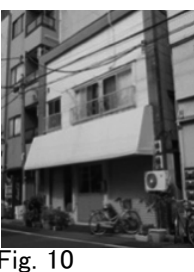

Fig. 10

Residential Elements
れない。滲み出しの要素として、自転車 91 軒・植栽 50 軒(Fig.10)・ 自動車 36 軒・業務利用 27 軒(Fig.9)などが見られた(数值は述べ数)。

\section{4. エリアスケールにおける職住混在空間特性}

\section{1. 建物類型の分布}

現地踏査物件による建物類型の数值結果を Table4、その立地を Fig.11 に示す。木造の A1 は北部の橋場・今戸地区で割合が高く、 $\mathrm{A} 2$ は全体的に散らばって立地している。A 3 は特に大通り沿いに立 地し、業務機能のみの B1 は浅草 $6 \cdot 7$ 丁目に多く立地している。

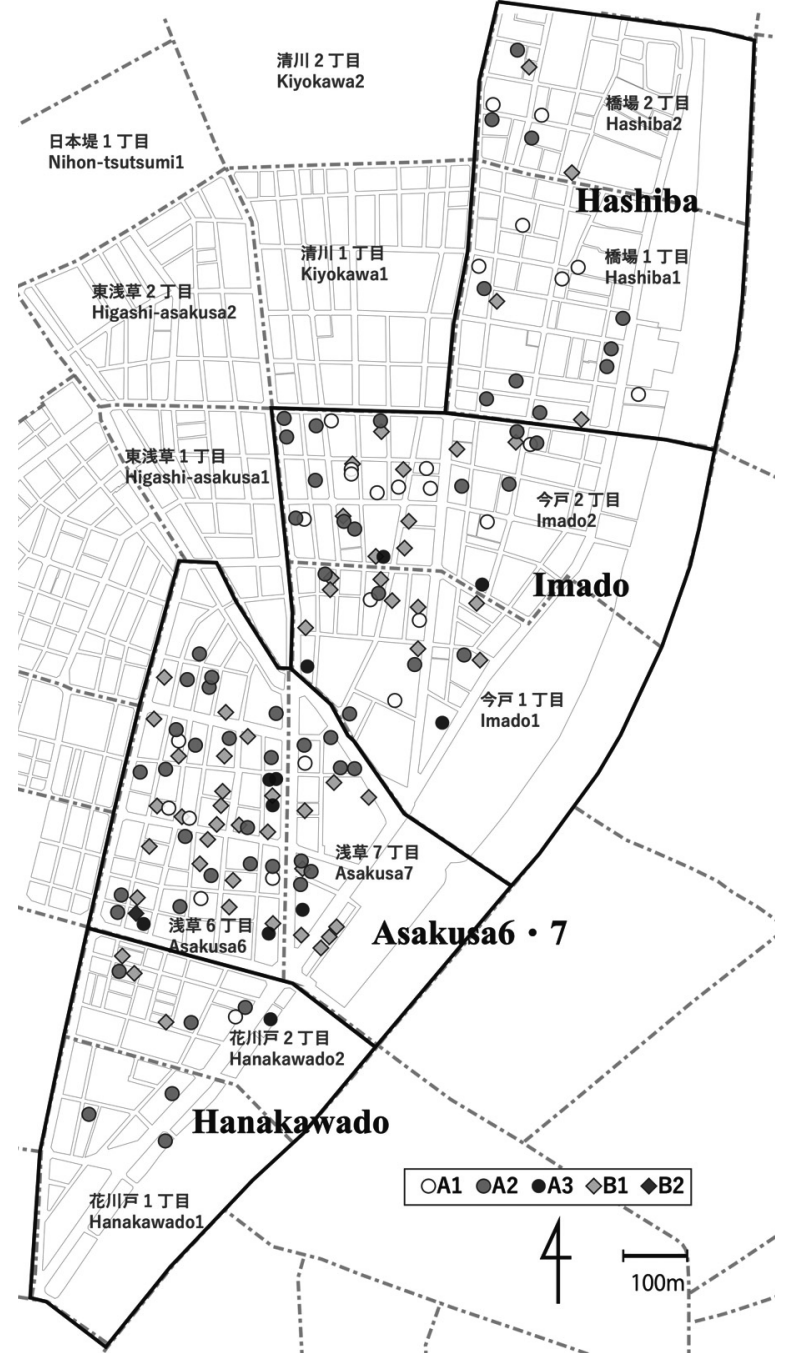

Fig. 11 Location of Building Types (by field survey)

Table 4 Number of Building Types by Area (by field survey)

\begin{tabular}{|c|c|c|c|c|c|c|}
\hline Number of Buildings & A1 & A2 & A3 & B1 & B2 & Total \\
\hline 橋場 : Hashiba & 7 & 10 & 0 & 4 & 0 & 21 \\
\hline 今戸 : Imado & 13 & 19 & 4 & 18 & 0 & 54 \\
\hline 浅草6,7: Asakusa6 $\cdot 7$ & 6 & 27 & 6 & 29 & 1 & 69 \\
\hline 花川戸 : Hanakawado & 1 & 6 & 1 & 3 & 0 & 11 \\
\hline Total & 27 & 62 & 11 & 54 & 1 & 155 \\
\hline
\end{tabular}

\section{2. 建物形態 (木造率・階高) と外観に見られる居住要素の分布}

木造率は橋場地区で高く、南部ほど低くなる傾向がある。逆に平 均階数は橋場地区で最も低く、北部の 2 地区が高い。バルコニーの 設置は地域間に大きな差は見られず、表札の掲示は橋場地区では半 数以上を占める。また、北部の 2 地区が滲み出しの割合が高い。総 じて、北部の 2 地区では中低層で居住要素が多く表出し、南部の 2 地区が中高層で居住要素の表出が少ない特性が見られる。（Fig.12）

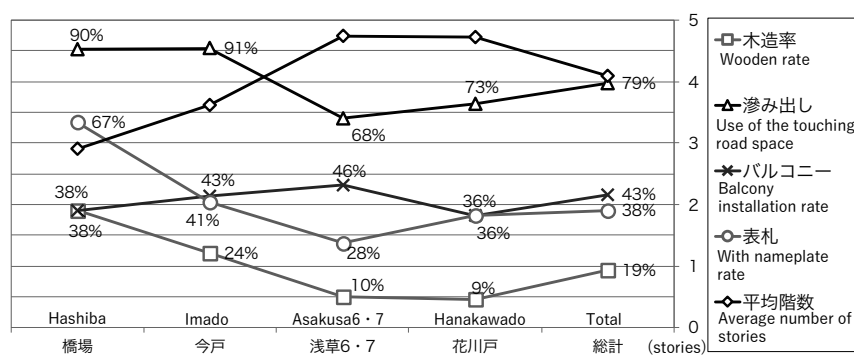

Fig. 12 Spatial Characteristics of Each Areas

\section{3. 台東区北部地域における職住混在空間のエリア特性}

E.Hoppenbrouwer \& E.Louw (2005) ${ }^{21)}$ の定義を用いると、類型 A は建築スケールの「Vertical(垂直) dimension」の混在、類型 B は建 築スケールで Vertical dimension 混在を有さない「Horizontal(水 平) dimension」の混在に分類できる。注 11) また A1・A2 と A3 は、 職住併存型都市住宅内の戸単位での居住空間の Vertical 混入率の差 で区別される。注 12) 対象地の職住混在空間の特性を Fig.13 に示す。 ・「職住併存型」混在地 : 建築スケールにおける Vertical dimension の混在を維持した更新の比率が高く、居住空間の Vertical(垂直)混 入率が低い状態で併存を維持して低中層での建替が進む地域であり、 主に橋場地区を中心に対象地北部に形成されている。

・「用途純化型」混在地：Vertical dimension の混在を有しない Horizontal dimension の混在が進み、かつ居住空間の Vertical(垂 直)混入率が高い地域。建築単体では業務若しくは居住機能に特化し 敷地単位で土地利用を棲み分けることでエリアとして職住混在空間 を保つ。浅草 $6 \cdot 7$ 丁目を中心に形成されている。

・「併存」十「用途純化」型混在地 : 少数ではあるが北部での B タイ プの立地や南部での A1 の立地も見られることから上記の混在特性 は明確な境界線は存在せず、連続的に変化していると考えられる。 そのため、今戸地区や花川戸地区などの隣接・中間に位置する地域 では双方の性質を包含する中間的な混在エリアが形成されている。

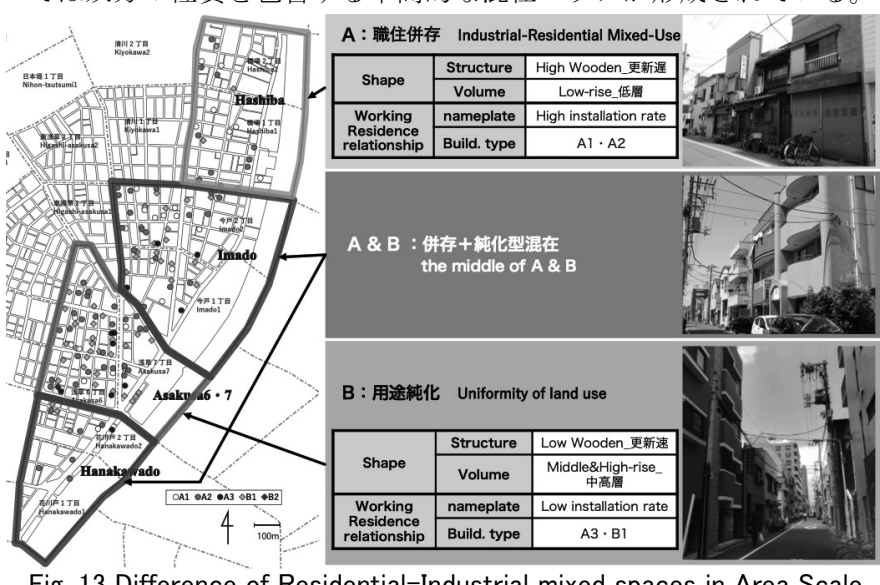

Fig. 13 Difference of Residential-Industrial mixed spaces in Area Scale 


\section{4. 職住混在空間特性と都市計画規制}

都市計画規制の効果を考察するため、指定される用途地域や容積 率等をFig.14に整理した。対象地は主に商業・近隣商業地域の商業 系用途が定められており、工場系用途は橋場地区の一部に留まる。 都心部に近い南部の 2 地区に、より高い容積率が指定されており、 南部の平均階高が高い要因の一つと考えられる。北部の 2 地区は平 成 7 年から特別用途地域の第二種中高層階住居専用地区が設定され、 人口の都心回帰に向け居住地としての性質を強める政策が取られて いる。幹線道路沿いは平成 9 年から最低限高度地区として高さの最 低限度が定められ、より高度な土地利用を目指寸方針が見受けられ る。範囲内に地区計画や建築協定等のルールは設定されていない。

建物類型の分布を重䄈ると、主に高度利用を目指すエリアに A3 が偏在している。一方で高容積がかけられているエリアに立地する $\mathrm{A} 1$ や北部地区に立地する B1 も存在し、A1・A2・B1 に関しては、 展開されている規制の影響をあまり受けないため、都市計画規制の 視点で見ると満遍なく立地していると考えられる。また橋場地区に は関東大震災や戦災の被害を免れた一部区画未整備街区が残ってお り、A1 が多い理由の一つとして考えられる。

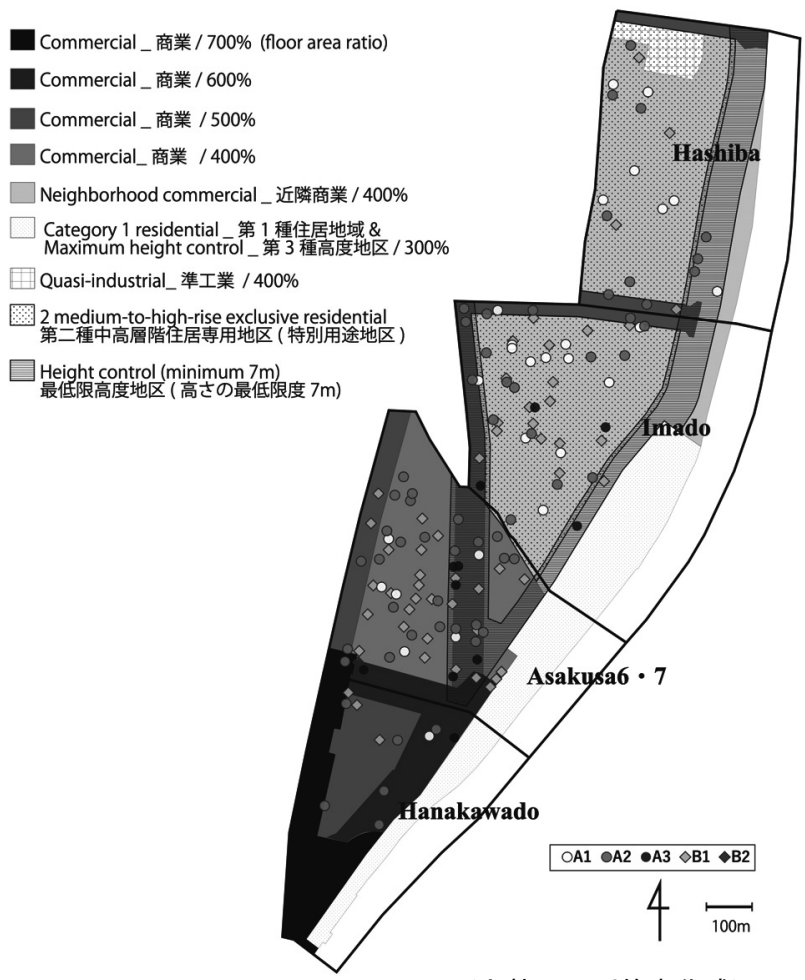

Fig. 14 Matching with City Planning Rules (文献 22 より筆者作成)

5. 地域産業空間構造から見た職住混在空間の形成と継承 5. 1. 産業部門別の職住混在空間特性

Fig.15 に皮革産業部門別で要素を再整理した。靴卸・靴製造部門 は中高層の割合が高く用途純化の傾向が強い一方、皮革製造販売・ 附属材料部門は職住併存の傾向が強く居住要素の表出傾向がある。 北部(橋場 - 今戸地区)には、附属材料(shoe parts)や皮革製造・販売 (Manufacturer \& Sale of leather) の業者の割合が高く、浅草 $6 \cdot 7$ 地区には満遍なく部門が分布、花川戸地区には卸(Shoe Wholesaler) 業者の割合が高い立地の偏りを踏まえると ${ }^{6)} 、 4$ 章で示した北部を 中心とした「職住併存型」混在の性質は附属材料および皮革製造販
売の職住混在空間特性、浅草 $6 \cdot 7$ 地区を中心とした「用途純化型」 の性質は靴製造と靴卸の職住混在空間特性と関係すると考えられる。

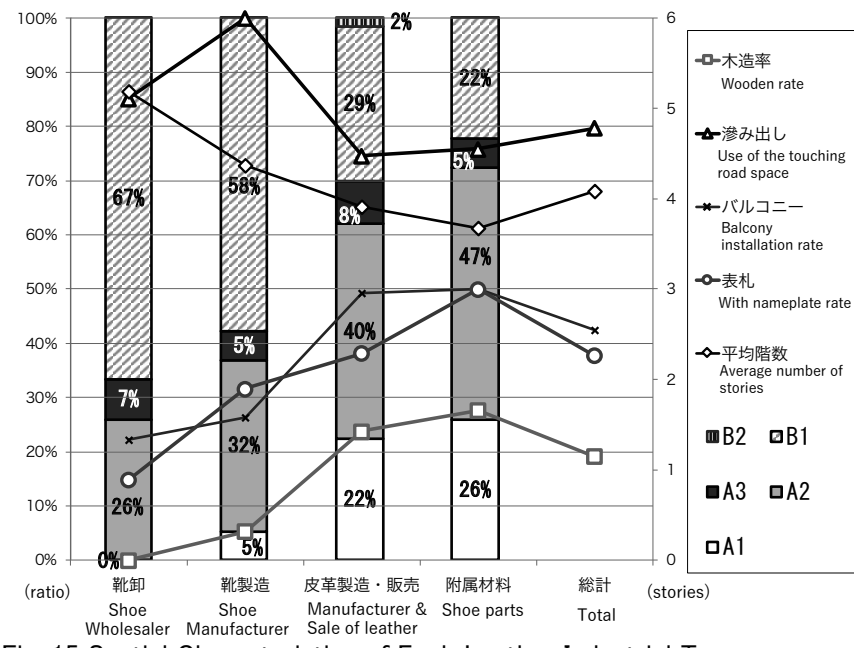

Fig. 15 Spatial Characteristics of Each Leather Industrial Type

\section{2. 混在空間特性と地域産業空間構造の重ね合わせによる考察}

考察のため、Fig.16 でエリア特性に産業部門を入れて整理した。 ・「附属材料」(Shoe Parts)部門で見ると、今戸地区により強い集積 がみられ、他地域と比べて特に A 1 の比率が高いのが特徴的である。 ・「皮革製造販売」(Manufacturer \& Sale of leather)部門で見ると、 南部に行くほど、類型 B の割合が高く、北部に行くほど類型 $\mathrm{A}$ の割 合が高い。特に橋場地区で木造(A1)の比率が高い。

・「靴製造」(Shoe Manufacturer)部門で見ると、特に今戸地区と浅 草 $6 \cdot 7$ 地区に集積が見られるが、今戸地区の方が B の傾向が高く、 全体の傾向とは異なる立地特性が見られる。

・「靴卸」(Shoe Wholesaler) 部門で見ると、浅草 $6 \cdot 7$ 地区と花川 戸地区に集積が見られ、特に浅草 $6 \cdot 7$ 地区に B 1 が多く形成されて いる。また他地区が主に B1 の事業所が多いのに対し花川戸地区の み類型 $\mathrm{A}$ の職住併存型都市住宅の割合が高いことが特徴的である。

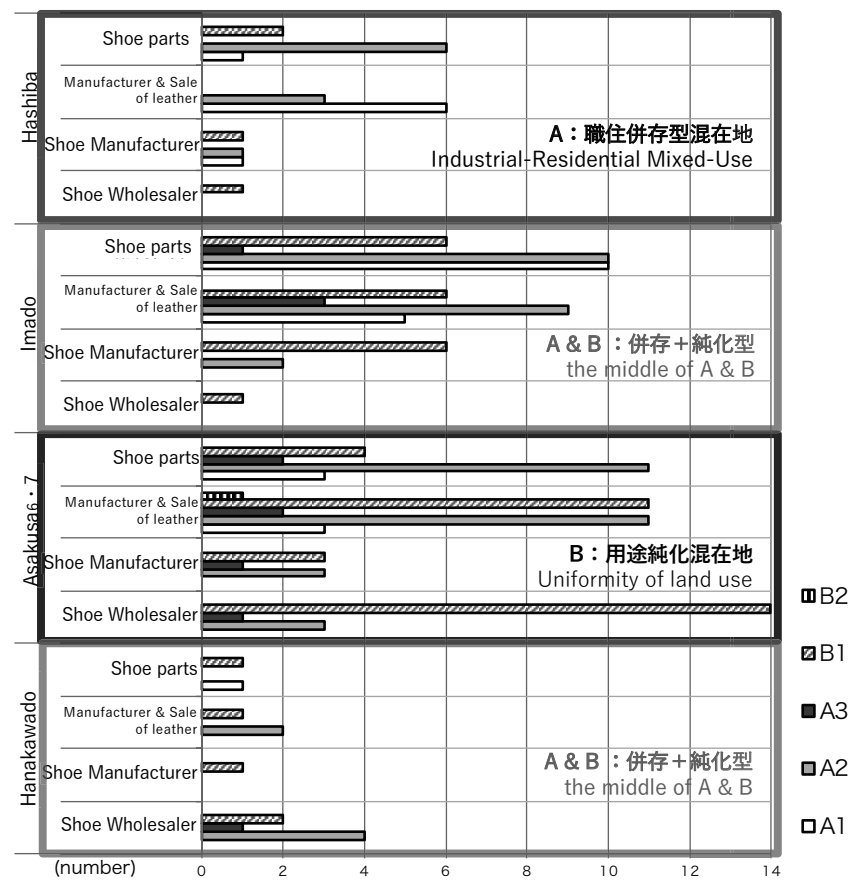

Fig. 16 The Number of Each Leather Establishments of Each 4 Areas 


\section{3. 地域産業空間構造の変遷から見た時空間的考察}

第 1 稿 ${ }^{6)}$ で調査した地域産業空間構造の変遷については、明治期 に東京都心部の縁辺部に立地していた対象地では商工分離時から卸 問屋・製造メーカー・下請製造加工の 3 タイプの事業所が主に存在 していたが、近代化市街地拡大に伴う商工分離の過程で、同心円状 の地域産業空間構造が外縁部へ拡大するような形で製造空間の商業 化が起こっていた。その同心円状の地域産業空間構造や産業構造の 変遷に、各事業所の個別更新の動きが重なり、本稿で明らかとなっ た建築スケールの職住混在空間の多様化と、「職住併存型」と「用途 純化型」の混在空間の形成に至ったと考えられる。

北部(橋場・今戸地区)では消失した製造空間を埋めるように参入 した産業部門の下請・個人経営的な性質や小規模空間での営業が可 能であったことなどの要因が重なり、従来の職住関係を維持した更 新による職住併存型混在空間が形成され、一方の浅草 $6 \cdot 7$ 丁目を 中心とした用途純化型混在空間の性質は、同心円状の地域産業空間 構造の内側に資本の大きい卸問屋や大規模化した製造メーカーが多 く立地していたことから、自社ビル化や不動産経営への移行が進み、 業務や居住に用途が特化した混在空間が形成されたと考察される。

\section{6. 結}

\section{1. 建築スケールで見た台東区北部の職住混在空間特性}

対象地の皮革関連産業事業所の約 8 割が非木造、6 割以上は 4 階 以下の建築物で構成されていた。対象事業所のうち「職住併存型都 市住宅」という事業と居住機能が建築スケールで併設された事業所 建築(類型 $\mathrm{A}$ )が職住関係及び形成過程により 3 種類抽出され、事業 所のみの建築(B1) と併せると、主に 4 種類の建物類型に分類された。

また、外観に見られる居住要素として、今後 A1 の更新などにお いて間口においてバルコニーの設置や入り口動線の分離、表札の掲 示などを伴う可能性が高く、職住併存型都市住宅の個別更新に伴い、 まち並み景観の変化等に影響を与える可能性がある。

\section{2. エリアスケールで見た台東区北部の職住混在空間特性}

対象エリアでは、主に 2 種類の職住混在空間特性が見られた、建 築スケールにおける「職住併存型」(Vertical dimension)の混在は、 橋場地区を中心に形成されており、小規模かつ低層に職住併存状態 を保ちながら更新している。間口における居住要素の表出率も高い。 一方「用途純化型」(Horizontal dimension)の混在は、浅草 $6 \cdot 7$ 丁 目を中心として形成され、建物単体での用途は純化し建物・敷地ス ケールでは機能特化しつつもエリアとしては混在性を保つ。間口に おける居住要素の表出率も低い。またこれらの性質は明確な境界線 は存在せずグラデーション的に変化しており、隣接する今戸地区や 花川戸地区では双方の性質をもつ中間的な混在空間が見られた。

\section{3. 地域産業空間構造から見た職住混在空間の形成と継承}

職住混在空間特性を司る要因として、産業構造上の機能が挙げら れ、北部を中心とした「職住併存型」混在の性質、および浅草 $6 \cdot 7$ 地区を中心とした「用途純化型」混在の性質は立地する皮革関連産 業の産業部門と関係していると考えられる。更に広域的な及びその 歴史的変遷から考察すると、それら混在空間の特性の違いは近代化 に伴う機能分離に伴い製造部門などが地域外に移転することで形成 された地域間機能分化構造と、地域内での地域産業空間構造の変遷 という大きな動きの中で、個別の事業所毎の事情に合わせた更新手
法が選択されていったことにより生じた現象であると推測される。

\section{4. 得られた示唆と今後の課題}

得られた示唆として、職住混在空間の実態把握においては、即地 的な職住混在空間の分析のみならず地域産業空間上の位置付けを考 慮することでより詳細に空間実態と形成要因の把握が可能である。 また個人事業主等による小規模な職住併存型混在空間では、同一建 物内に併設される居住空間と業務空間を分離して空間活用や管理利 用主体を考える視点が今後重要になると考えられる。

産業都市空間の持続可能性という観点からは、職住併存型や用途 純化型などの職住混在空間特性はその産業構造や職住関係が相互補 完的に更新されることで継承されているので、地域内部・地域間双 方の視点での機能分化構造や地域産業空間構造のバランス関係で見 ていく必要がある。

今後の課題として、従業員の職住関係及び不動産の所有などの権 利関係も空間特性に影響を与える可能性、地域間で機能分化する他 地域との関係や社会的背景などを踏まえた考察、などが挙げられる。

なお、本研究の第 3 章までの部分は、第 18 回国際都市計画史学会 (IPHS 2018 Yokohama)において「The Characteristics and Changes in Residential-Industrial Mixed Buildings in the Taito Leather Industrial District in Tokyo」の題目で梗概並びに口頭発表を行った。

\section{謝辞}

調査に尽き対象地並びに周辺の公的機関・事業者・関係者の方々 に多くの御協力をいただいた。この場を借りて感謝の意を示したい。

\section{参考文献}

1) Tokyo Metropolitan Government: city planning area master plan, 2014 東京都：都市計画区域の整備、開発及び保全の方針, 2014

2) Cabinet Office: The 5th Science and Technology Basic Plan, 2016 内閣府 : 第 5 期科学技術基本計画, 2016

3) Ministry of Health, Labour and Welfare : The guidebook for telework, 2016 (in Japanese)

厚生労働省 : テレワークではじめる働き方改革一テレワーク導入・運用ガ イドブック, 2016

4) Hatori, Y. and Kishimoto, T.: Study on usage mixture of collective housings in Tokyo 23 wards, Journal of City Planning Institute of Japan, Vol. 40, pp. 163-168, 2005 (in Japanese)

羽鳥洋子, 岸本達也: 東京 23 区における集合住宅の用途混合の実態に関 寸る研究，都市計画論文集, Vol. 40, pp. 163-168, 2005

5) Nohara, T.: Study on Planning Concepts and actual Development of Urban Industrial Spaces in Japan, Doctoral dissertation, The University of Tokyo, 2009 (in Japanese) 野原卓:日本の工業都市空間における計画概念とその実践的展開に関する 研究-生産空間と生活空間の関係性に着目して, 東京大学博士論文, 2009

6) Hamada, M., Nakajima, N. and Nishimura, Y.: Regional - Industrial Structure in Northern Taito, Journal of Architecture and Planning (Transactions of AIJ), Vol. 83, No. 750, pp. 1469-1476, 2018. 8 (in Japanese)

演田愛，中島直人，西村幸夫：皮革関連産業構造の変遷から見た台東区北 部地域の地域産業空間構造, 日本建築学会計画系論文集 Vol. 83, No. 750, pp. 1469-1476, 2018. 8

7) Ide, S.: Distribution of Consumer Goods Industries and Manufacturing Structure in Tokyo, Geographical Review of Japan, Vol. 39, No.11, pp. 730-743, 1966 (in Japanese)

井出策夫：大都市日用消費財工業の地域構造, 地理学評論, Vol. 39,No. 11, pp. $730-743,1966$

8) Ide, S.: On the Regional Structure of Small Industries Concentrated 
Area in Large Cities, Geographical Review of Japan, Vol. 46, No. 10, pp. 668-674, 1966 (in Japanese)

井出策夫：大都市零細産業集団地域の内部構造, 地理学評論, Vol. 46, No. 10, pp. 668-674, 1973

9) Takeuchi, A.: The Integrated Industrial-Residential areas of Tokyo, Geographical Review of Japan, Vol. 47, No. 12, pp. 748-760, 1974 (in Japanese)

竹内淳彦：東京内部における住工混在地域の構造-荒川区・大田区の分析-, Geographical Review of Japan, Vol. 47, No. 12, pp. 748-760, 1974

10) Nakade, B.: Transition of the Production Environment and a New Phase of Mixed (Industrial and Residential) Land Use in Ota-ku, Tokyo, City Planning Review, Vol. 17, pp. 283-288, 1982 (in Japanese) 中出文平: 大田区住工混在地域における生産環境の変容と新たなる混在の 進行に関する考察 (昭和 57 年度 [日本都市計画学会] 学術研究発表会論文 集-17-), 都市計画 別冊, Vol. 17, pp. 283-288, 1982

11) Nakade, B.: Transition of the Environment in a Mixed (Industrial and Residential) Land Use Area in Tokyo-ku-area, City Planning Review, Vol. 18, pp. 373-378, 1983 (in Japanese)

中出文平: 東京都区部の住工混在地域における居住・生産環境の変容の考 察 (昭和 58 年度日本都市計画学会学術研究発表会論文集-18-), 都市計画 別冊, Vol. 18, pp 373-378, 1983

12) Nagano, K.: Current Land Use of Stagnant Industrial Areas in Otaku, Tokyo -Toward Revitalization of Urban Industrial Complex-, City Planning Review, Vol. 22, pp. 193-198, 1987 (in Japanese)

永野和邦：工業系地域における土地利用動向-一大田区工業地域における調 査分析 (昭和 62 年度 [日本都市計画学会]学術研究論文集), 都市計画 別冊, Vol. 22, pp. 193-198, 1987

13) Wada, M. and Nakai, N.: The Change of Residential-Industrial Mixed Use at the Street Block Level-A Case Study at Ota Ward-, Papers on city planning, Vol. 27, pp. 505-510, 1992 (in Japanese) 和田真理子, 中井検裕: 街区レベルでみた住工混在地区の土地利用変化に 関する研究--大田区大森地区の事例（1992 年度[日本都市計画学会]学術研 究論文集), 都市計画論文集, Vol. 27, pp. 505-510, 1992

14) Wada, M. and Nakai, N.: The process of Land-Use Change in Residential-Industrial Mixed Use Area and Minimum, Papers on city planning, Vol. 29, pp. 493-498, 1994 (in Japanese) 和田真理子, 中井検裕: 住工混在地区における土地利用変化のプロセスと 最低敷地面積制限に関する研究 (1994 年度[日本都市計画学会]学術研究論 文集), 都市計画論文集, Vol.29, pp493-498, 1994

15) Sakuma, Y., Goto, H. and Sato, K.: Difference between Residence and work about Use Separated from Building Type, Journal of Architecture and Planning (Transactions of AIJ), Vol. 74, No. 639, pp. 1085-1093, 2009. 5 (in Japanese)

佐久間康富, 後藤春彦, 佐藤賢一: ニット産業の事業所建築物における外 観からは見えない用途の混在, 日本建築学会計画系論文集, Vol. 74, No. 639, pp. 1085-1093, 2009. 5

16) Shimizu, Y. and Nakayama, T.: Research on Evaluation of Entrepreneur and Resident on Residential-Industrial Mixed Land Use Area and City Planning of Residential-Industrial Coexistence, Journal of Architecture and Planning (Transactions of AIJ) ,Vol. 72, No. 612, pp. 71-78, 2007. 2 (in Japanese)

清水陽子, 中山徹: 住工混在地の事業者と工場跡地に建てられた住宅に住 む住民の意識と, 住工共存のまちづくりに関する研究, 日本建築学会計画 系論文集, Vol. 72, No. 612, pp. 71-78, 2007. 2

17) Okuma, M. and Nohara, T.: A Study on the Network Based on the Industrial Co-operation in the Residential-Industrial Mixed Use Area, Journal of City Planning Institute of Japan, Vol. 46, No. 3, 2011 (in Japanese)

大熊瑞樹, 野原卓: 住工共存地域における工場連携を基盤とした地域ネッ トワークの重層性に関する研究：都市計画論文集, Vol. 46, No. 3, pp. 493498, 2011

18) Zenshin: Shoe Industry Directory ver. 1970, 1969 (in Japanese) ぜんしん：靴産業名鑑 1970 版, 1969

19) Town Page -2016 Arakawa Ward ver., 2016 (in Japanese) タウンページ-2016 年荒川区版, 2016

20) Zenrin: Zenrin Residential Map -Tokyo ,2016. 7 (in Japanese)
ゼンリン：ゼンリン住宅地図，東京都, 2016. 7

21) Hoppenbrouwer, E. and Louw, E.: Mixed-use development - Theory and practice in Amsterdam's Eastern Docklands, European Planning Studies, Vol. 13, No. 7, pp. 967-983, 2005

22) Taito-City: Taito City planning map, 2014. 4

台東区: 台東区都市計画図, 2014. 4

23) Taito-City: Taito Landscape planning, 2011. 12 (in Japanese) 台東区：台東区景観計画, 2011. 12

24) Hibata, Y. and Yasunaga, S.: A Study on a Land Use Control System from a Viewpoint of a Survey for the Mixed Land Use in "Yamanote" Sub-CBD Belt Area of Tokyo, Journal of City Planning Institute of Japan, Vol. 26, pp. 163-168, 1991 (in Japanese)

日端康雄, 安永臣吾: 東京の都心周辺住宅地の用途混在化と用途別容積制, 都市計画論文集, Vol. 26, pp. 163-168, 1991

25) Hamada, M., Nakajima, N. and Nishimura, Y.: The Characteristics and Changes in Residential-Industrial Mixed Buildings in the Taito Leather Industrial District in Tokyo, IPHS 2018 Yokohama conference, abstract No. 127, Yokohama Japan, 2018. 7

注

注 1) 野原 (2009) では「居住空間」に近く生産空間や就労空間の範囲的な意味 と、「人間の活動空間全体」という意味の、2 種類の生活空間を定義してい る。本研究では主に前者の「居住空間」としての生活空間に着目する。

注 2) 問屋が製造部門を拡充独立させたものと、メーカーと呼ばれるかつての 職人 (下職)が変化したものとがある。

注 3) タウンページの項目における、「皮革・製革」「皮革材料」「皮革製品 製造」「皮革製品卸」「靴材料」「靴製造・卸」の事業所。

注 4）但し産業上の部門が分析において重要であるため、「靴製造・卸」は第 1 稿で示した方法で判別が可能であったもののみを対象とした。

注 5) 台東区景観計画に於いて台東区北部エリアとして指定されている 20 町 丁目 (橋場 $1 \cdot 2$ 、今戸 $1 \cdot 2$ 、三八輪 $1 \cdot 2$ 、清川 $1 \cdot 2$ 、日本堤 $1 \cdot 2$ 、東浅 草 $1 \cdot 2$ 、浅草 $3 \cdot 4 \cdot 5 \cdot 6 \cdot 7$ 、千束 $3 \cdot 4$ 、竜泉 $3($ 丁目) )に、花川戸 $1 \cdot 2$ 丁目を加えた 22 町丁目における皮革関連事業所。

注 6)うち 2 件は同一事業所が隣接しない 2 箇所の敷地に立地していたが、本 研究では事業所建築単体に着目するため異なる建物として算出した。また 既往研究である佐久間 (2009)において「事業所の分類」で示されていた「複 棟」に関しては、本研究の方法上データを得られなかったため類型には含 んでいないが、現地踏査の際には在庫の運搬や即売会の実施などで近隣 (隣 接・対向の敷地等)の建物を複数利用していると思われる空間利用の実態を 複数目にした。これら近距離間での徒歩や自転車による業務移動が道路空 間の使われ方や賑わい等にも地域特性を付与している可能性も考えられる。 注 7) デパートのテナントやマンションの一室の非居住用途利用などの現象も 事業所の形態のあり方を考察する上で重要であるが、事業所固有の建物形 態を重視する本調査においては分析の対象外とした。

注 8) 但し、木造・非木造の判断は筆者の現地における目視判定による。

注 9)ここでいう「事業所的建築」と「集合住宅的建築」とは佐久間 (2009)で 使用される分類指標であり、開口部にバルコニー等住宅要素の付設がある ものを「集合住宅的建築」、そのような設えがないものを「事業所的建築」 と分類している。但し A-2 の様に一世帯のみ居住する場合も同様に居住要 素が表出する場合がある為、本研究では住宅の設えがあるものを「住宅的 建築」とし、更に「職住併存的住宅」と「集合住宅的建築」の 2 つに分類 した。これらはエントランスや複数の郵便受けの有無によって判断した。 注 10) 但し、個人名に限り、組織名・法人名はカウントしていない。

注 11) E.Hoppenbrouwer \& E.Louw(2007)では、Mixed Use の類型を構成す る四つの変数(Functions of housing and working, Dimension, scale and urban texture) の一つとして、4 種類の dimensions(Shared premises, Horizontal, Vertical and Time)を提唱している。

注 12) 類似の議論として、日端 (1991) は用途混在の指標に、(1)平面的混入率(建 物の棟と敷地が対応するとみて敷地単位の全敷地に対する非住居系建物の 件数比)、(2)立体的混入率(建物の各住戸ごとの用途を区分し、全住戸に対す る非居住用途の戸数比)、(3)住居用建物立体的混入率(住居用建物の全住戸 に対する非住居用途の戸数比）、の 3 分類を使用している。一方本研究の類 型 A は、戸単位で業務または居住に特化した空間の同一建物内での混在で あり、日端(1991)の「住居用建物立体混入」とは異なる概念である。（但し、 調査の方法上類型 A 中にも住居用建物立体混入が含まれる可能性がある。） 
SPATIAL CHARACTERISTICS OF RESIDENTIAL-INDUSTRIAL MIXED-USE AREA

IN NORTHERN TAITO-WARD FROM THE VIEWPOINT OF LEATHER INDUSTRY BUILDINGS

A study on the fact and inheritance of urban Residential-Industrial mixed-use area

from the view of Regional-Industrial structure Part2

\author{
Megumi HAMADA ${ }^{* 1}$, Naoto NAKAJIMA ${ }^{* 2}$ and Yukio NISHIMURA ${ }^{* 3}$ \\ ${ }^{* 1}$ Grad. Student, Dept. of Urban Engineering, School of Engineering, The University of Tokyo, M.Eng. \\ *2 Assoc. Prof., Dept. of Urban Engineering, School of Engineering, The University of Tokyo, Dr.Eng. \\ ${ }^{* 3}$ Prof., Graduate school of Kobe Design University, Dr.Eng.
}

In recent years, the developments in existing urban areas of Tokyo are reorganizing the population composition and its spatial characteristics through increase in size and scale of spaces. On the other hand, small-scale spatial infrastructures are also attracting attention for the flexible ways of working regardless of time or places. So, there is a need to discuss that how to renew the existing urban area while simultaneously creating a sustainable urban and local industry space. Aims to get suggestions for that, this study focuses on the leather industrial area, which has mixed use spaces from modern times in the existing urban area of Tokyo.

The present study aimed to (1)xamine the fact of the spatial characteristics of leather industry establishments in a building scale main owned by individual owners and (2)grasp the trend of the present Residential-Industrial mixed-use spaces in Tokyo through the analysis of the results in area scale. Finally, by discussing the results based on the historical transition of Regional-industrial structure, we intend to (3)extract the inherited essence in the renewal process of urban Residential-Industrial mixed-use areas.

Firstly, the target area; Northern Taito Ward, is an area where the leather industry was established during the early modern times, which were dominated by the wholesale and secondary processing industry on a family scale. Individual buildings in which residence and workshop functions are combined are a popular style in this area. We researched the spatial characteristics of 155 leather industry buildings on site and created four building types for analysis.

-A1 : Wooden buildings built as residence and workshop functions that are combined in the ratio of 1:1.

-A2 : Non-wooden buildings rebuilt as residence and workshop functions that are combined in the ratio of 1:1.

-A3 : Non-wooden buildings rebuilt as residence and workshop functions that are combined in a ratio of multiple:1.

-B1 : Non-wooden buildings rebuilt for workshop functions only.

It was found that A2 type building is the most popular style in this area. In part, some tenants enter the low-rise part of collective houses (A3). Both are Residential-Industrial mixed-use buildings, which have been renewed keeping the industrial and community networks at the ground level. In addition, there is a trend of separating the access flow lines to each residence and workshop functions by making different entrances in A2/A3 type buildings, that shows the tendency of the separation progress of the relationships between residential-spaces and work-spaces even within one building.

Secondly, there are the tendency of Residential-Industrial mixed-use spaces, that the north part is more wooden, lowrise and like to be rebuilt keeping the Residential-Industrial mixed-use styles, on the other hand, the south part is more non-wooden, middle- or high-rise and like to be rebuilt in uniformity of land use. These types of Residential-Industrial mixed-use buildings are different depending on the function of industrial category; like wholesale, manufacturer and so on. We already found distribution of the area by the industrial position and the tend to be distributed, and it turned out that commercialization occurred in the whole area in the last paper (Part1). Consequently, from the view of area analysis, it is thought that there is some kind of relation between the special characteristics of the urban residential-industrial mixed-use buildings and the regional-industrial structure of leather industry.

In conclusion, it is possible to grasp the real situation of the Residential-Industrial mixed-use space and its formation factors in more detail by considering the positioning in the Regional-Industrial structure, in addition to analysis based on the regional location. Then, it is necessary to think about the Residential-Industrial relationships and the RegionalIndustrial structure in the mixed spaces based on the balance between both inside and outside of regional structure of the area. 